Ivaniuk, I. V., Ovcharuk, O. V. (2021). Rezultaty onlain-opytuvannia. Hotovnist i potreby vchyteliv shchodo vykorystannia tsyfrovykh zasobiv ta IKT v umovakh karantynu: 2021. Analitychnyi zvit. [The results of an online survey of teachers' readiness and needs for the use of digital tools and ICT in quarantine: 2021. Analytical report]. Kyiv: IITZN NAPN Ukrainy. URL: https://lib.iitta.gov.ua/724564 (data zvernennia: 30.05.2021). [in Ukrainian].

Ivaniuk, I. V., Ovcharuk, O. V. (2020). Stan hotovnosti pedahohiv ZZSO do zastosuvannia informatsiino-osvitnoho seredovyshcha dlia zdiisnennia dystantsiinoho navchannia v umovakh karantynu, sprychynenoho COVID-19 [The state of readiness of teachers of Secondary Schools to use the information and educational environment for the implementation of distance learning in quarantine caused by COVID-19]. Nova pedahohichna dumka. № 3 (103). S. 48-54. [in Ukrainian].
Ivaniuk, I., Ovcharuk, O. (2020). The response of Ukrainian teachers to COVID-19: challenges and needs in the use of digital tools for distance learning. Informational Technologies and Learning Tools. T. 77. № 3. Pp. 282-291. URL: https://doi.org/10.33407/itlt.v77i3.3952 (Accessed: 30.05.2021). [in English].

Ovcharuk, O., Ivaniuk, I., Soroko, N., Gritsenchuk, O. \& Kravchyna, O. (2020). The use of digital learning tools in the teachers' professional activities to ensure sustainable development and democratization of education in European countries. E3S Web of Conferences. 166 (10019). URL: https://www.e3s-conferences.org/articles/e3sconf/ abs $/ 2020 / 26 /$ e 3 sconf icsf2020 10019/e 3 sconf icsf2020 10019.html (Accessed: 30.05.2021). [in English].

Bykov, V. Yu. ta in. (2008). Tekhnolohiia stvorennia dystantsiinoho kursu [Technology of creating a distance course]. Kyiv: Milenium. 324 s. [in Ukrainian].

Дата надходження до редакиії: 16.09.2021 p.

\section{Неля КIHАX,}

кандидат економічних наук, доиент кафедри педагогіки та психології Волинського інституту післядипломної педагогічної освіти, м. Луцьк, Украӥна ORCID: 0000-0002-9025-6514 e-mail:nelyakinax@gmail.com

Наталія РУБЛЬОВА, заступник директора з проєктної діяльності та платних послуг

Волинського інституту післядипломноі педагогічної освіти,

м. Луцьк, Украӥна

ORCID: 0000-0001-8341-7095

e-mail:n.rublova@vippo.org.ua

\title{
ПІДВИЩЕННЯ ФАХОВОГО РІВНЯ ВЧИТЕЛІВ ПОЧАТКОВОЇ ШКОЛИ У КОНТЕКСТІ ЦИФРОВОГО ПІДПРИЕМНИЦТВА
}

\begin{abstract}
Анотація. У статті досліджено особливості навчання вчителів початкової иколи цифровому підприсмнииттву з метою підвищення їх фахового рівня, шуо зумовлено иифровізачією освітнього середовища, яке вимагає від вчителя нових професійних знань та вмінь, аналізу методів та прийомів роботи з молодшими школярами. Зміст цифрової компетентності обтрунтовано з урахуванням критичного й відповідального використання ичфрових технологій та взаємодії з ними впродовж навчання, професійної діяльності та життя у складних умовах сьогодення. Окреслено ключові завдання щзодо навчання цифрровому підприємництву, котрі передбачають: створення новітніх освітніх иифрових продуктів, бізнес-практик, інформаційних ресурсів із ведення ичифрового підприємництва; розробку нової якості ичифрових навчальних
\end{abstract}

ресурсів з урахуванням особливостей стилів сприйняття матеріалу та рівня професійного розвитку, трансформації, модернізаиії й адаптації підприємництва в умовах мінливого освітнього середовита. Визначено результати навчання ичифровому підприємництву, що формують нову якість компетениій учителів початкової школи з метою набуття ичиррових навиків підприємництва, оволодіння новітніми цчифровими інструментами, щчо використовуються в ході навчання циифровому підприємництву з метою становлення нової якості співпраці та комунікаиії, та новітніми технологіями е-навчання в умовах віртуальної реальності.

Ключові слова: иифрова компетентність, иифровізація, ичифрове підприємництво, циифрові технології, иифрова освіта. 
Nelia KINAKH,

Candidate of Economic Sciences,

Associate Professor,

Associate Professor at the Department

of Pedagogy and Psychology,

Volyn Institute of

Postgraduate Pedagogical Education,

Lutsk, Ukraine

ORCID: 0000-0002-9025-6514

e-mail:nelyakinax@gmail.com

Natalia RUBLIOVA,

Deputy Director for Project Activities and Paid Services,

Volyn Institute of Postgraduate Pedagogical Education,

Lutsk, Ukraine

ORCID: 0000-0001-8341-7095

e-mail:n.rublova@vippo.org.ua

\section{IMPROVING THE PROFESSIONAL LEVEL OF PRIMARY SCHOOL TEACHERS IN THE CONTEXT OF DIGITAL ENTREPRENEURSHIP}

\begin{abstract}
The article examines the peculiarities of primary school teachers' training in digital entrepreneurship in order to improve their professional level, due to the digitalization of the educational environment. This requires new professional knowledge and skills, reviewing methods and techniques of working with younger students.

It has been justified content of digital competence and taking into account the critical and responsible use of digital technologies, interaction with them during training, professional activities and life in today's difficult conditions.

It has been outlined the key tasks for training in digital entrepreneurship wich provide: creation of the latest educational digital products, business practices, information resources for digital entrepreneurship, development of a new quality of digital educational resources on digital entrepreneurship, transformation, modernization and adaptation of entrepreneurship in a changing educational environment and taking into account the peculiarities of the styles of perception of the material and the level of professional development.

In the course of obtaining education in digital entrepreneurship in order to improve the professional level of primary school teachers should conduct trainings and webinars on the following topics: "Innovative methods of teaching digital entrepreneurship in primary school in the new virtual reality», "Educational and scientific priorities of digital entrepreneurship in modern information society", "Innovations of digital educational space in modern realities of information space», «Digitalization of education of Ukraine and the EU in the conditions of innovation and globalization.

It has been identified results of digital entrepreneurship training that form a new quality of primary school teachers' competencies for acquiring digital business skills. Which also includes latest digital tools used in digital entrepreneurship training to establish a new quality of
\end{abstract}

cooperation and communication and the latest e-learning technologies virtual reality.

Key words: digital competence, digitalization, digital entrepreneurship, digital technologies, digital education.

Постановка проблеми. На сучасному етапі розвитку освіти в Україні важливе значення має не формування конкретних вимог до педагогів, а певного стандарту, опису, переліку знань і вмінь учителів із розкриттям їхніх компонентів. Такий опис передбачено Концепцією розвитку педагогічної освіти, а також планом заходів Нової української школи до 2029 року. Цифровізація суспільного життя та професійної діяльності будь-якого фахівця і педагога зокрема нині досягла піку актуальності. Швидкий розвиток інформаційно-комунікаційних технологій в освітньому середовищі вимагає від учителя нових професійних знань та вмінь, перегляду методів та прийомів роботи з молодшими школярами. Відповідно до Державного стандарту початкової освіти оновлення української школи потребує впровадження в освітню діяльність інформаційно-комунікаційних технологій (Професійний стандарт за професіями «Вчитель початкових класів закладу загальної середньої освіти», «Вчитель закладу загальної середньої освіти», «Вчитель з початкової освіти (з дипломом молодшого спеціаліста)», 2020). Згідно з реалізацією Концепції «Нова українська школа» (далi - НУШ) визначаються вимоги щодо формування цифрової грамотності вчителів початкової освіти. Один із ключових компонентів формули НУШ $\epsilon$ розвиток цифрової компетентності педагогічних працівників закладів освіти, що передбачає використання вчителями початкових класів ІКТ із метою реалізації творчого потенціалу та підвищення якості освітнього процесу в умовах інформаційного суспільства.

Цифрова компетентність педагога - це не лише технічні навички, а й знання, зосереджені на когнітивних, 
соціальних й емоційних аспектах діяльності та життя в мінливому середовищі, яке вимагає знання питань підприємництва. Самі вчителі своєю професійною діяльністю маркують потребу навчання підприємництву, адже: 3'являється можливість використовувати інформаційне та віртуальне освітнє середовище для пошуку, обміну та публікування інформації; реалізується навчання на основі новітніх технологій та використання розвиваючих ігор; формуються освітній маркетинг та управлінські навички планування, організації, управління, контролю, керівництва; розвиваються навички фінансової грамотності, організаційно-правової діяльності, комунікативні навички та навички мислення проблемно-підприємницького спрямування; виробляється здатність брати на себе відповідальність за вирішення проблем та їх креативне розв'язання тощо.

Аналіз наукових досліджень і публікацій. Вплив процесу цифрових технологій на розвиток підприємництва аналізуються у працях багатьох учених. Вагомий внесок у дослідження означеного питання зробили А. Андерсон, О. Симсерт, П. Дойль, П. Друкер, Н. Краус, К. Клаус, Г. Боуман, А. Томпсон, Е. Тоффлер, Р. Акофф, А. Остервальдер, Е. Ламбертон, М. Стівен, В. Апалькова, С. Волосович, В. Плескач, І. Ковшов, О. Криворучко, С. Коляденко, Л. Лазаренко, С. Веретюк, С. Войтко, І. Малик, П. Стецюк, В. Фіщук, К. Шваб, М. Сафрончук та ін. Актуальні проблеми підприємницької діяльності та підприємницької підготовки в українській освіті в останні роки є предметом досліджень В. Андріанової, 3. Гіптерс, Г. Назаренко, В. Майковської, О. Романовського, В. Шабанової та ін.

Із дослідженням загальних аспектів цифровізації, інноватизації та комплексної модернізації освіти XXI століття та проблем їх адаптації до глобального інноваційно-цифрового простору пов'язані імена Н. Андрусяк, Л. Болдирєвої, І. Брітченко, О. Голобородька, В. Гройсмана, А. Кубіва, О. Криворучко, П. Леоненка, О. Манжури, О. Марченка, М. Однорога, Ю. Пивоварова, С. Синягова та ін. Однак значна кількість проблем, таких як формування якісної моделі трансформації традиційної освіти у цифрову в Україні, особливості освітнього процесу та змісту підготовки до цифрового підприємництва вчителів початкової школи залишаються недостатньо дослідженими й потребують детального вивчення. Крім того, відсутнє чітке уявлення про основні результати навчання цифровому підприємництву, що формують нову якість компетенцій педагогів із метою набуття цифрових навиків підприємництва.

Мета статті - представити авторське бачення освітнього процесу підготовки до цифрового підприємництва вчителів початкової школи в системі неперервної освіти та окреслити його зміст; проаналізувати можливості нових форм та видів робіт, що формують цифрові компетенції та навички в ході здобуття освіти iз цифрового підприємництва, та надати методичні рекомендації з навчання цифровому підприємництву як базового структурного ядра на етапі трансформації освіти; визначити основні результати означеного навчання, що формують нову якість компетенцій учителя початкової школи для набуття цифрових навиків підприємництва.
Виклад основного матеріалу дослідження. Досвід упровадження моделі цифрової підготовки вчителів початкової школи у контексті освітнього підприємництва свідчить, що цифрові технології, незважаючи на всю ефективність, $є$ не метою, а засобом сучасної освіти. Цифровізація освіти дає змогу інтенсифікувати освітній процес, збільшити швидкість та якість сприйняття, розуміння і засвоєння знань (Краус, 2019, с. 6). Вдалим результатом цифровізації освіти буде іiі успішне функціонування в рамках «цифрового трикутника» (Краус Н., Краус К., Болдирєва Л., 2019), що представлений на рисунку.

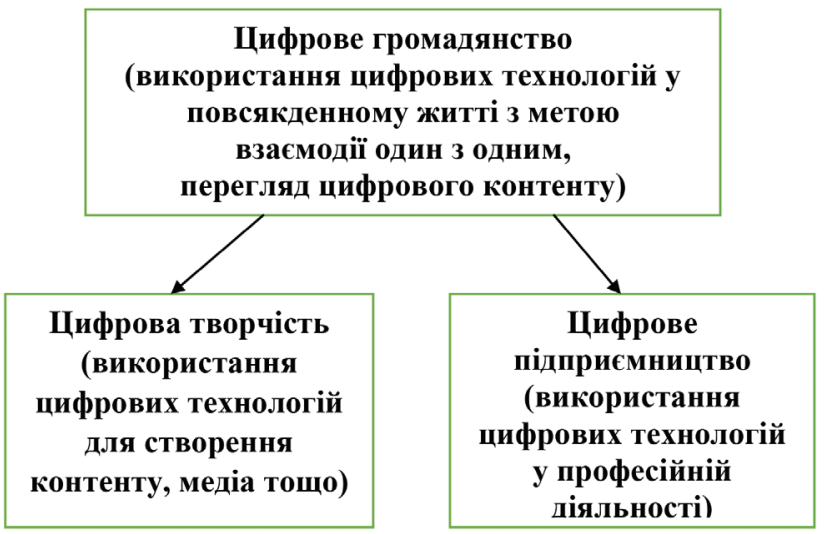

Рис. Базова модель циифрового трикутника, щзо продукує циифрова освіта

Освітні цифрові технології дають змогу зробити процес навчання мобільним, диференційованим, індивідуальним, цікавим та насиченим. За цієї умови новітні освітні технології не замінюють вчителя, а доповнюють його. Таким заняттям притаманні адаптивність, керованість, інтерактивність, поєднання індивідуальної та групової роботи, часова необмеженість навчання. Освітні цифрові технології відкривають перед учителем нові можливості, дають змогу разом з учнями отримувати задоволення від спілкування та пізнання в ході навчання. Варто наголосити, що глобальна інформатизація суспільства потребує змін методичних підходів до підготовки та проведення уроків. У зв'язку 3 цим для вдосконалення освітнього процесу педагогам необхідно використовувати інформаційно-комунікаційні технології, що підвищуватиме рівень викладання, наближатиме результати навчання до стандартів освіти, допомагатиме враховувати різні умови навчання та рівні підготовки учнів. Урок із використанням IКТ наочно економить час педагога й учня, дозволяє здобувачу освіти працювати у власному темпі, а вчителю допомагає працювати з учнями індивідуально й диференційовано, забезпечує оперативний контроль та оцінювання результатів навчання.

Доцільними критеріями відбору методів і форм підготовки учнів до підприємницької діяльності $€$ відповідність методів навчання: принципам, меті, завданням і змісту інноваційної освітньої діяльності; навчальним можливостям учнів (віковим, психологічним, гендерним); умовам навчання; передбаченому планом часу на засвоєння навчальної інформації; рівню майстерності педагогічних працівників тощо. Кожен педагог самостійно визначає оптимальні для свого 
заняття методи, що повинні допомогти учням свідомо сприймати інформацію, бути активними у процесі навчання, забезпечувати здатність до самореалізації та самоствердження.

Цифрова компетентність передбачає впевнене, критичне та відповідальне використання та взаємодію із цифровими технологіями з метою навчання, роботи й участі в суспільстві (Гринько, 2019). Здобувач освіти повинен розуміти, як цифрові технології можуть підтримувати комунікацію, творчість та інноваційність, усвідомлювати їхні можливості, обмеження, наслідки і ризики (див. табл. 1).

Таблиияя 1

Цифрові компетенції, що продукує цифрова освіта

\begin{tabular}{|c|c|}
\hline Цифрові компетенції & $\begin{array}{c}\text { Зміст та загальна характеристика } \\
\text { цифрових компетенцій }\end{array}$ \\
\hline Цифровий контент & $\begin{array}{l}\text { уміння змінювати, поліпшувати, використовувати цифровий контент для створення нового } \\
\text { контенту; обізнаність щодо авторських прав та політики ліцензування даних }\end{array}$ \\
\hline Вирішення проблем & $\begin{array}{l}\text { уміння вирішувати технічні проблеми, що виникають із комп’ютерною технікою, програм- } \\
\text { ним забезпеченням, мережами; знаходити відповідні технічні рішення або кастимізувати } \\
\text { цифрові технології до власних потреб; вміння самостійно визначати потребу в отриманні } \\
\text { додаткових цифрових навичок }\end{array}$ \\
\hline $\begin{array}{l}\text { Комунікація та } \\
\text { взаємодія }\end{array}$ & $\begin{array}{l}\text { уміння спілкуватися, ділитися інформацією, використовувати цифрові технології; вміння } \\
\text { контактувати із суспільством, користуватися державними і приватними послугами завдяки } \\
\text { цифровим технологіям }\end{array}$ \\
\hline $\begin{array}{l}\text { Інформаційна } \\
\text { грамотність } \\
\text { та грамотність щодо } \\
\text { роботи } 3 \text { даними }\end{array}$ & $\begin{array}{l}\text { уміння відбирати, фільтрувати дані, оцінювати інформацію; використовувати та керувати } \\
\text { даними й цифровим контентом }\end{array}$ \\
\hline Безпека & $\begin{array}{l}\text { уміння захистити пристрої та контент, знання заходів безпеки, розуміння ризиків і загроз; } \\
\text { захист персональних даних і приватності; розуміння впливу цифрових технологій на ек-- } \\
\text { логію; знання та навички щодо збереження свого здоров'я }\end{array}$ \\
\hline
\end{tabular}

Цифровізація освіти, проголошена в Концепції розвитку цифрової економіки та суспільства України на 2018-2020 роки, зумовила потребу в модернізації процесу підвищення кваліфікації педагогів на загальних засадах діджиталізації освітнього простору і розгляді цифрової компетентності як ключової в означеному аспекті. Різноманіття вимірів цифровізації освіти визначає розгляд усіх складових такого процесу на різних рівнях: світовому (глобальному), державному (національному), регіональному (місцевому) та на рівні діяльності викладача та здобувача освітніх послуг. У зв'язку з цим розгляд проблеми підвищення фахового рівня вчителя початкової школи варто розпочинати з визначення реально існуючого стану цифрової компетентності педагогів на місцях, а їі формування є процесом постійним та послідовним.

Недостатня розробленість у теорії й методиці питання формування цифрової компетентності педагогів в умовах цифровізації освітнього процесу зумовили пошук шляхів щодо розв'язання означеної проблеми. Виникла необхідність розглядати нові напрями розвитку цифрової компетентності педагогів, що передбачають методологічний, структурно-змістовий, операціонально-діяльнісний і діагностично-результативний підходи. Зважаючи на це, можна стверджувати, що означена проблема є багатоаспектною та складається з багатьох вимірів. Широкий спектр її напрямів вимагає комплексного аналізу всіх етапів комп'ютеризації освітнього процесу в освітніх закладах та пов'язаних із ними психолого-педагогічних особливостей професійної діяльності вчителів, змін і тенденцій, що спостерігаються у формах, методах, засобах і технологіях педагогічної діяльності.

Освітні цифрові технології дозволяють зробити процес навчання цифрового підприємництва мобільним, диференційованим, індивідуальним, цікавим та насиченим. Таким заняттям притаманні адаптивність, керованість, інтерактивність, поєднання індивідуальної та групової роботи, часова необмеженість навчання цифровому підприємництву

Найбільш затребувані форми та види робіт, що формують цифрові компетенції та навички в ході здобуття освіти 3 цифрового підприємництва в системі неперевної освіти, представлено в таблиці 2, що сформована авторами на основі відповідних джерел (Краус Н, Краус К., Болдирєва Л, 2019).

Освітні цифрові технології відкривають перед учителем початкової школи нові можливості, дозволяють отримувати задоволення від спілкування 3 учнями, пізнання в ході навчання та оволодіння цифровими компетенціями й уміннями. Крім того, дають змогу вчителю автоматизувати значну частину його роботи, вивільняючи людський ресурс на пошук, спілкування, індивідуальну роботу з учнями, уможливлюють отримання миттєвого зворотного зв'язку, покращують ефективність управління навчальним і дослідним процесами та самоосвітою. 
Форми і види робіт, що формують цифрові компетенції та навички в ході здобуття освіти 3 цифрового підприсмництва в системі неперервної освіти

\begin{tabular}{|c|c|}
\hline $\begin{array}{c}\text { Форми навчання, } \\
\text { що застосовуються в ході } \\
\text { здобуття знань } \\
\text { із цифрового підприсмництва }\end{array}$ & $\begin{array}{l}\text { Види, зміст та характерні особливості } \\
\text { здобутих компетенцій і набутих знань }\end{array}$ \\
\hline $\begin{array}{l}\text { Тренінги, що присвячені } \\
\text { набуттю цифрових підприєм- } \\
\text { ницьких навиків }\end{array}$ & $\begin{array}{l}\text { під час участі в тренінгах відбувається впровадження в практику: нових цифрових } \\
\text { освітніх продуктів із методики розвитку критичного мислення, громадської } \\
\text { й правової цифрової освіти, дебатів, цифрової освіти для сталого інноваційно- } \\
\text { цифрового розвитку; інтерактивних технологій цифрового навчання, освітнього } \\
\text { менеджменту; активного навчання; дослідження і структурування інформаційно- } \\
\text { цифрового простору через навчання мисленнєвим операціям високого рівня } \\
\text { у процесі роботи } 3 \text { цифровою інформацією та великими текстами; системи } \\
\text { роботи з інформацією / текстами різноманітного змісту та обсягу за допомогою } \\
\text { графічних організаторів (конструкторів) }\end{array}$ \\
\hline $\begin{array}{l}\text { Вебінари із цифрового } \\
\text { підприємництва }\end{array}$ & $\begin{array}{l}\text { у ході ознайомлення з кращими європейськими практиками у сфері цифрової } \\
\text { освіти і цифрової науки в умовах нової віртуальної реальності, «вирощуван- } \\
\text { ня» на цій основі власного інституту цифрової освіти, інституту цифрового } \\
\text { підприємництва }\end{array}$ \\
\hline $\begin{array}{l}\text { Самостійна робота } 3 \text { питань } \\
\text { ведення цифрового бізнесу }\end{array}$ & $\begin{array}{l}\text { розвиток критичного мислення як можливість висловлювати власну пози- } \\
\text { цію у цифровому підприємництві; творчий пошук щодо розвитку цифрового } \\
\text { підприємництва }\end{array}$ \\
\hline $\begin{array}{l}\text { «Круглі столи», присвяче- } \\
\text { ні проблемам цифровізації } \\
\text { підприємництва }\end{array}$ & $\begin{array}{l}\text { обговорення і дискусія з питань ведення цифрового підприємництва на таких } \\
\text { заходах; запитання як інструмент викладача } 3 \text { цифрового підприємництва }\end{array}$ \\
\hline $\begin{array}{l}\text { Офлайн-навчання та } \\
\text { онлайн-навчання }\end{array}$ & $\begin{array}{l}\text { критичне мислення і аргументація у формуванні та захисті наукової й навчаль- } \\
\text { ної позиції: уміння визначати аргументи в різних текстах, формулювати ар- } \\
\text { гументи на підтримку позиції, створювати систему аргументацій у власному } \\
\text { навчально-науковому тексті (стаття, доповідь, виступ, реферат, стартап-проєкт, } \\
\text { випускна робота, аналітична записка); визначення та спростування некоректної } \\
\text { аргументації, захист від інформаційної маніпуляції }\end{array}$ \\
\hline
\end{tabular}

У процесі здобуття освіти 3 цифрового підприємництва варто проводити тренінги та вебінари iз таких тем: «Інноваційні методики навчання цифровому підприємництву у початковій школі в умовах нової віртуальної реальності», «Освітньо-наукові пріоритети навчання цифровому підприємництву в сучасному інформаційному суспільстві», «Новації цифрового освітнього простору в сучасних реаліях інформаційного простору», «Цифровізація освіти України та ЄС в умовах інноватизації та глобалізації».

Водночас у ході освітнього процесу варто використовувати методичні рекомендації з навчання цифровому підприємництву, метою яких є сприяти підвищенню рівня сформованості цифрової компетентності щодо ведення підприємництва педагогів, їх здатності ефективно використовувати цифрові техніки, методики, бізнес-технології в практико орієнтованому освітньому процесі (Манжура, 2019).

Завданнями методичних рекомендацій із навчання цифровому підприємництву є:

- створення новітніх освітніх цифрових продуктів, бізнес-практик, інформаційних ресурсів із ведення цифрового підприємництва; освіти;

- подальший розвиток цифровізації у закладах

- розробка нової якості цифрових навчальних ресурсів із цифрового підприємництва з урахуванням особливостей стилів сприйняття матеріалу та рівня розвитку, трансформації, модернізації й адаптації підприємництва в умовах посилення інноваційної глобалізації;

- застосування цифрових інструментів із метою ефективної комунікації та співпраці в ході навчання цифровому підприємництву в умовах віртуальної реальності;

- поширення застосування цифрових технологій у цифровому підприємництві в освітньому процесі;

- розвиток у вчителів компетенцій, здатності та відчуття необхідності до постійного саморозвитку і самовдосконалення цифрових навичок, ведення підприємницької діяльності, застосування інноваційних педагогічних, цифрових технологій та онлайн-сервісів у процесі навчання.

Результатами навчання цифровому підприємництву повинні бути володіння цифровою грамотністю та формування професійних компетенцій підприємницького змісту і нової якості, що відповідатимуть європейським стандартам (Марченко, 2020). Основні результати навчання цифровому підприємництву, котрі визначають та формують нову структуру і якість компетенцій учителя початкової школи щодо відцифрування інноваційної підприємницької діяльності, представлено в таблиці 3, що складена авторами на основі відповідних джерел (Манжура О., Краус Н., Краус К., 2019, 2020). 
Основні результати навчання цифровому підприємництву, що формують нову якість компетенцій учителя початкової школи для набуття цифрових навиків підприємництва

\begin{tabular}{|c|c|}
\hline $\begin{array}{l}\text { Цільове спрямування } \\
\text { цифрових інструментів }\end{array}$ & $\begin{array}{c}\text { Зміст та характерні особливості } \\
\text { результатів навчання цифровому підприсмництву }\end{array}$ \\
\hline $\begin{array}{l}\text { Новітні цифрові інстру- } \\
\text { менти, що } \\
\text { використовуються в ході } \\
\text { навчання цифровому } \\
\text { підприємництву }\end{array}$ & 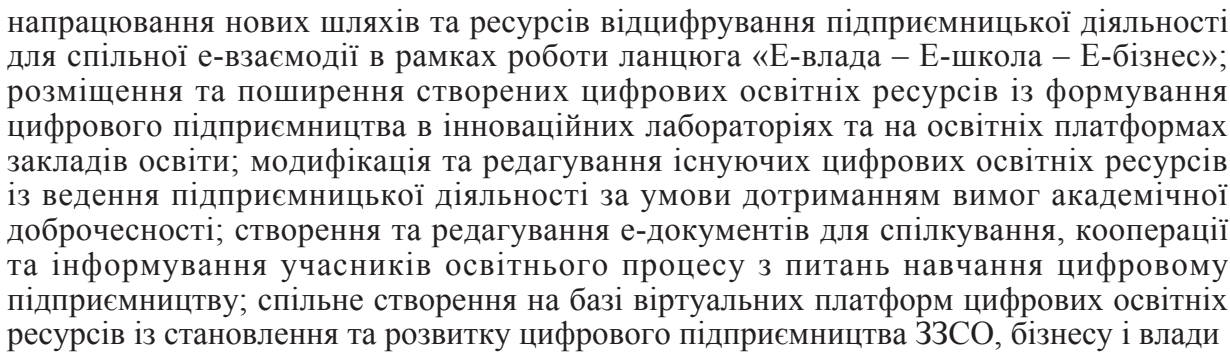 \\
\hline $\begin{array}{l}\text { Цифрові інструменти, } \\
\text { що використовуються в } \\
\text { ході навчання цифрово- } \\
\text { му підприємництву } 3 \text { ме- } \\
\text { тою становлення нової } \\
\text { якості комунікації }\end{array}$ & $\begin{array}{l}\text { використання цифрових інструментів для вирішення практичних кейсів із метою } \\
\text { формування нової якості комунікації під час навчання цифровому підприємництву в } \\
\text { умовах віртуальної реальності; організація онлайн-спілкування між усіма учасниками } \\
\text { освітнього процесу за допомогою соціальних мереж, корпоративних сервісів, } \\
\text { системи е-навчання; оперативне консультування всіх учасників освітнього процесу } \\
\text { інструментами цифрового середовища закладів освіти }\end{array}$ \\
\hline $\begin{array}{l}\text { Інноваційні цифрові } \\
\text { інструменти для фор- } \\
\text { мувального оцінювання } \\
\text { рівня здобутих знань і } \\
\text { компетенцій у } \\
\text { результаті нав- } \\
\text { чання цифровому } \\
\text { підприємництву }\end{array}$ & $\begin{array}{l}\text { розробка та відпрацювання критеріїв оцінювання якості створених навчальних е-курсів, } \\
\text { е-ресурсів різного формату із цифрового підприємництва в умовах нової віртуальної } \\
\text { реальності; застосування цифрових інструментів із метою вирішення завдань щодо } \\
\text { об’єктивного та прозорого оцінювання набутих компетенцій, навиків і здібностей у } \\
\text { результаті навчання цифровому підприємництву в умовах віртуальної реальності }\end{array}$ \\
\hline $\begin{array}{l}\text { Новітні технології е-нав- } \\
\text { чання цифровому під- } \\
\text { приємництву в умовах } \\
\text { віртуальної реальності }\end{array}$ & 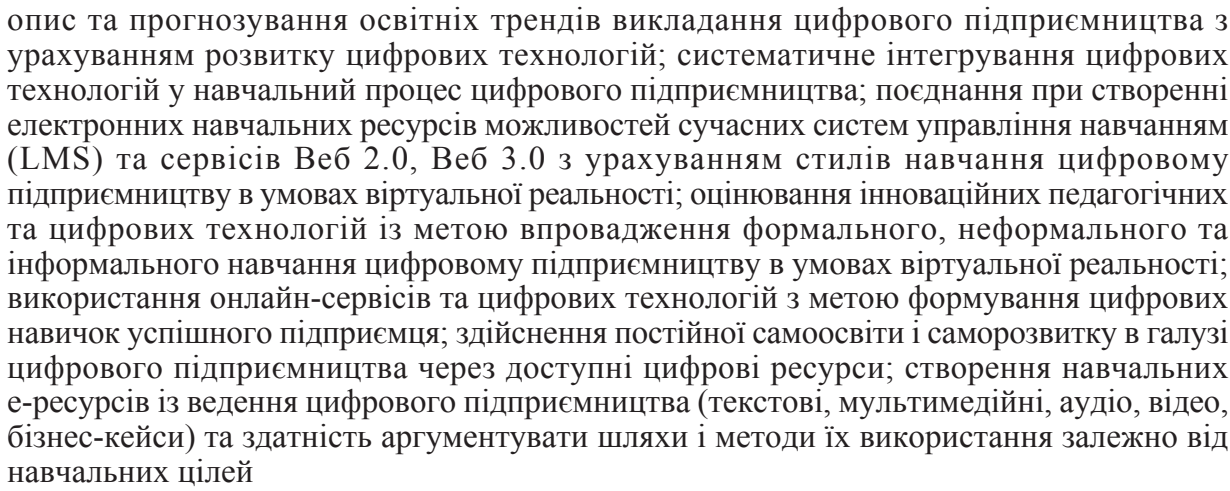 \\
\hline
\end{tabular}

Використання у процесі навчання здобувачів освіти методичних рекомендацій щодо особливостей змісту викладання цифрового підприємництва дає змогу вчителю початкової школи: оволодіти новими методами, техніками, технологіями цифрового навчання в умовах нової віртуальної реальності; набути цифрових компетентностей для формування навичок ведення підприємницької діяльності; формувати важливі якості, затребувані сьогоденням; удосконалювати рівень цифрових навиків і здібностей щодо ефективного і безпечного використання цифрових технологій для вирішення професійних завдань (Манжура, 2020). У звязку з цим застосування новітніх методів у системі неперервної освіти з метою підвищення рівня компетентності з ведення цифрового підприємництва вчителів початкової школи відповідно до затверджених європейських стандартів є досить актуальним, на що й спрямовані означені рекомендації 3 навчання цифровому підприємництву.
Висновки. Отже, варто зазначити, що застосування «цифрових» технологій у ході навчання (здобуття освіти) цифровому підприємництву наразі є одним із найважливіших тенденцій розвитку світового освітнього процесу. Вони дозволяють інтенсифікувати освітній процес, збільшити швидкість та якість сприйняття, розуміння й засвоєння знань із цифрового підприємництва. Враховуючи невідворотність подальшої «цифровізації» як глобального, так і національного явища, реформування освіти має відбуватися з урахуванням потреб розвитку віртуально-реального та інноваційно-цифрового простору, «Суспільства 5.0», цифрового підприємництва, наукових можливостей, нових потреб та викликів, що постають перед освітньою спільнотою в результаті COVID-19. Використання «цифрових» технологій в освіті має кросплатформовий (наскрізний) характер, тобто йдеться про використання новітніх технологій не лише на уроках інформатики в початковій 
школі, а й при взаємодії учнів один з одним та 3 учителями під час здійснення досліджень, у ході індивідуального навчання цифрового підприємництва тощо. Ми глибоко переконані, що існує нагальна потреба щодо кращої поінформованості педагогів стосовно цифрових цінностей змісту та методики навчання цифровому підприємництву.

Перспективи подалыших досліджень. Незважаючи на масштабність наявних наукових здобутків, все ж важливо в майбутньому відпрацювати освітню стратегію у галузі навчання цифровому підприємництву в умовах неперервної освіти, що дозволило б мати на ринку освітніх послуг компетентних учителів відповідно до потреб ринку цифрових послуг та продуктів.

\section{СПИСОК ВИКОРИСТАНОЇ ЛІТЕРАТУРИ}

Гринько, В. (2019) Використання цифрових технологій для формування у майбутніх учителів умінь XXI століття. Молодь і ринок. Дрогобич: ДПУ ім. Франка. № 5. С. 56-62.

Краус, Н., Краус, К., Болдирєва, Л. (2019) Цифрові компетенції у сфері вищої освіти: задум, реалізація, результат. Держава та регіони. Серія «Економіка та підприємництво». Київ. № 1 (106). С. 4-10.

Криворучко, О., Краус, Н., Краус, К. (2018). Вipтуальна реальність національного інформаційно-інноваційного простору. Економіка та суспільство. Мукачево. № 14. С. 22-35.

Манжура, О., Краус, Н., Краус, К. (2020). Економічна професійна освіта покоління цифрових людей в умовах функціонування інноваційно-підприємницьких університетів. Бізнес інформ. Харків. №3. С. 182-191.

Манжура, О., Краус, Н., Краус, К. (2019). Професії майбутнього у віртуальній реальності інноваційно-цифрового простору. Бізнес інформ. Харків. №1. C. 132-138.

Марченко, О., Краус, Н., Краус, К. (2020). Інноваційне підприємництво і цифровий бізнес: науково-економічна фіча розвитку та зміни в управлінні. Ефективна економіка: електронне наукове видання. URL: http://www.economy.nayka.com.ua/?op=1\&z=7779 (дата звернення: 10.09.2021).

Професійний стандарт за професіями «Вчитель початкових класів закладу загальної середньої освіти», «Вчитель закладу загальної середньої освіти», «Вчитель 3 початкової освіти (з дипломом молодшого спеціаліста)». (2020) / Міністерство розвитку економіки, торгівлі та сільського господарства України. URL: https://nus.org.ua/wp-content/uploads/2020/12/ Nakaz 2736.pdf (дата звернення: 23.08.2021).

Цифрова адженда України - 2020 («Цифровий порядок денний» - 2020). Концептуальні засади (версія 1.0). Першочергові сфери, інічіативи, проєкти «цифрровізації» України до 2020 року: електронне видання. URL: https:/ucci.org.ua/uploads/files/58e78ee3c3922.pdf (дата звернення: 12.09.2021).

\section{REFERENCES}

Hrynko, V. (2019) Vykorystannia tsyfrovykh tekhnolohii dlia formuvannia u maibutnikh uchyteliv umin KhKhI stolittia [The use of digital technologies for the formation of future teachers' skills of the XXI century]. Molod i rynok. Drohobych: DPU im. Franka. № 5. S. 56-62. [in Ukrainian].

Kraus, N., Kraus, K., Boldyrieva, L. Tsyfrovi kompetentsii u sferi vyshchoi osvity: zadum, realizatsiia, rezultat [Digital competencies in the field of higher education: design, implementation, result]. (2019). Derzhava ta rehiony. Seriia «Ekonomika ta pidpryiemnytstvo». Kyiv. № 1 (106). S.4-10. [in Ukrainian].

Kryvoruchko, O., Kraus, N., Kraus, K. (2018). Virtualna realnist natsionalnoho informatsiino-innovatsiinoho prostoru [Virtual reality of the national information and innovation space]. Ekonomika ta suspilstvo. Mukachevo. № 14. S. 22-35. [in Ukrainian].

Manzhura, O., Kraus, N., Kraus, K. (2020). Ekonomichna profesiina osvita pokolinnia tsyfrovykh liudei $\mathrm{V}$ umovakh funktsionuvannia innovatsiino-pidpryiemnytskykh universytetiv [Economic professional education of the generation of digital people in the conditions of functioning of innovative and entrepreneurial universities]. Biznes inform. Kharkiv. № 3. S. 182-191. [in Ukrainian].

Manzhura, O., Kraus, N., Kraus, K. (2019). Profesii maibutnoho u virtualnii realnosti innovatsiino-tsyfrovoho prostoru [Professions of the future of innovation and digital space in the virtual reality]. Biznes inform. Kharkiv. № 1. S. 132-138. [in Ukrainian].

Marchenko, O., Kraus, N., Kraus, K. (2020). Innovatsiine pidpryiemnytstvo i tsyfrovyi biznes: naukovo-ekonomichna ficha rozvytku ta zminy v upravlinni [Innovative entrepreneurship and digital business: scientific and economic features of development and changes in management]. Efektyvna ekonomika: elektronne naukove vydannia. URL: http://www.economy.nayka.com.ua/?op=1\&z=7779 (data zvernennia: 10.09.2021). [in Ukrainian].

Profesiinyi standart za profesiiamy «Vchytel pochatkovykh klasiv zakladu zahalnoi serednoi osvity», «Vchytel zakladu zahalnoi serednoi osvity», "Vchytel z pochatkovoi osvity (z dyplomom molodshoho spetsialista)» [Professional standard by professions «Primary school teacher of general secondary education», «Teacher of general secondary education», «Primary teacher (with a diploma of junior specialist)»]. (2020) / Ministerstvo rozvytku ekonomiky, torhivli ta silskoho hospodarstva Ukrainy. URL: https:// nus.org.ua/wp-content/uploads/2020/12/Nakaz 2736.pdf (data zvernennia: 23.08.2021). [in Ukrainian].

Tsyfrova adzhenda Ukrainy - 2020 («Tsyfrovyi poriadok dennyi» - 2020). Kontseptualni zasady (versiia 1.0) [Digital Agenda of Ukraine - 2020 («Digital Agenda» 2020). Conceptual principles (version 1.0).]. Pershocherhovi sfery, initsiatyvy, proekty «tsyfrovizatsii» Ukrainy do 2020 roku: elektronne vydannia. URL: https:/ucci. org.ua/uploads/files/58e78ee3c3922.pdf (data zvernennia: 12.09.2021). [in Ukrainian]. 